\title{
Virulence-genes Rib and Bca in Serotypes of Group B Streptococcus (GBS) Isolated from Symptomatic Pregnant Women in East Coast Malaysia
}

\author{
Ayesha B. ${ }^{a, b}$, Imad A. D. M. ${ }^{a}$, Hairul A.H. ${ }^{a}$, Hanan H. W. ${ }^{a}$ \\ ${ }^{a}$ Department of Basic Medical Science, Kulliyyah of Medicine, International Islamic University Malaysia (IIUM) \\ ${ }^{b}$ Department of Microbiology and Parasitology, Kabul University of Medical Sciences (KUMS), Karte Sakhi, Kabul, Afghanistan
}

\begin{abstract}
INTRODUCTION: Group B streptococcus (GBS) is a leading cause of maternally-acquired invasive infections in neonates. Nowadays maternal immunization is of utmost demand for prevention of these infections. We undertook capsular serotyping and virulence factor genes identification for local GBS isolates as a pilot study, to identify potential candidates to propagate vaccine development. MATERIALS AND METHODS: This is a descriptive lab -based study to determine GBS serotypes and presence of genes coding virulence factors bca and rib in isolates obtained from symptomatic pregnant women in Hospital Tengku Ampuan Afzan, Kuantan, Pahang, Malaysia. Sixty-two GBS isolates from high vaginal swabs were collected. Latex agglutination test was performed to determine GBS

Keywords

Group B streptococcus (GBS), Virulence Factor, Serotypes, Capsular Polysaccharide (CPS)

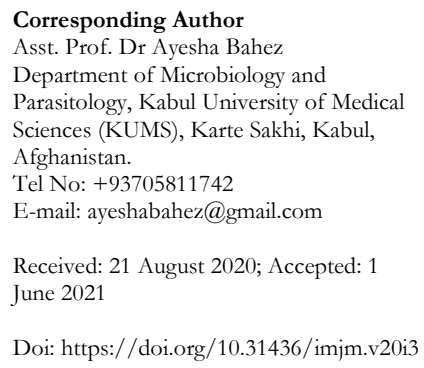

RESULTS: Of the 62 GBS isolates, $77.4 \%$ were serologically typeable, and $22.6 \%$ were non -typeable. Serotypes Ia and Ib (16.1\% each) were the most common capsular types, followed by II, V, and VII (9.7\% each), III (8.1\%), VI (6.5\%), and VIII (1.6 \%). Furthermore, $67.7 \%$ of the isolates harboured the rib gene while $98.4 \%$ possessed the bca gene. CONCLUSION: The five known prevalent serotypes worldwide, do not match the CPS distribution in symptomatic pregnant women in Kuantan. However, the frequency of virulence genes rib and bca is high among our isolates, which if confirmed by further bigger and wider studies makes the proteinaceous vaccine, $\mathrm{N}$-terminal domains of Rib and AlpC a suitable candidate for GBS prevention in this geographical area.
\end{abstract}

\section{INTRODUCTION}

Streptococcus agalactiae or Group B Streptococcus (GBS) is one of the pathogens which colonization is common in pregnancy and leads to perinatal infection. ${ }^{1}$ Nowadays, GBS is a known pathogen in neonates causing newborn and infant pneumonia, meningitis, and septicemia. ${ }^{2}$

GBS lives as part of resident bacterial flora of the vagina and gastrointestinal tract. ${ }^{3}$ Maternal heavy colonization at lower genital tract and extreme prematurity of newborn make the primary risk factors for neonate early -onset disease (EOD), onset within the first seven days of life, and late onset disease (LOD), onset within the 7-
90 days of life. ${ }^{4}$ The prevalence of recto-vaginal colonization in pregnant women is high ranging from 10-30\%. 5 North America, Europe, and Australia had similar prevalence rate (15-21\%), with a slightly higher rate in Southern Africa (25\%), and lower one in Western Africa (14\%), Central America (10\%), and South, South-Eastern, and East Asia (9\%-12\%). ${ }^{6}$ According to review by Huang in 2016, GBS carriage in pregnant women was $10 \%$ worldwide, being significantly lower in Asia (7\%) compared with nonAsian countries $(19 \%) .{ }^{7}$ A study from a teaching hospital in Malaysia reported that the vaginal carriage rate of GBS in pregnant women to be $9.7 \% .8$

IMJM Volume 20 No.3, July 2021 
Preventive measures for perinatal GBS disease were implemented in 1990s as a result of the collaborative efforts of clinicians, researchers, professional organizations, parent advocacy groups, and the public health community in the United States, but neonatal sepsis cases are still significantly high in the United States and many other countries of the world. According to Eskandarian a 2014 study from a teaching hospital in Malaysia reported the annual incidence of GBS septicaemia in babies to be 0.4/1000 live-births. ${ }^{9}$ The Centre for Disease Control and Prevention (CDC) and other relevant professional bodies have published guidelines for prevention of perinatal GBS disease, ${ }^{10}$ which are very effective in identifying and treating women with GBS infections. Intrapartum antibiotic prophylaxis (IAP) is one of the most important CDC recommendations but it had no effect on reducing neonate LOD. Vaccination of pregnant women could possibly protect neonates against GBS EOD, and also LOD through trans-placental transfer of serotypespecific capsular IgG antibody. ${ }^{11}$

In addition, immunization of pregnant women may also protect against foetal loss/stillbirths and defective neurodevelopment following neonatal sepsis. ${ }^{11}$ GBS genome encodes numerous virulence factors that permit it to persist in the harsh vaginal environment. These virulence factors include capsular polysaccharides (CPS), surface proteins, and pili proteins. CPS enable GBS to survive in the host cell by preventing activation of the complement pathways involved in opsonophagocytosis and thus mediating GBS immune-evasion and pathogenesis. ${ }^{5}$ GBS is classified into ten serotypes Ia, Ib, II-IX according to the structure of the CPS.12 Type specific capsular classification has been performed by capillary precipitation, commonly known as the Lancefield method. ${ }^{13}$ Inhibition enzyme linked immunosorbent assays (iELISA), ${ }^{12}$ are also used for serotype determination. To overcome limitations in serotype classification, molecular based typing techniques for the identification of the gene loci coding type specific CPS have been developed. Molecular techniques were seen as highly desirable because of their high discriminatory power, reproducibility, and specificity. ${ }^{14}$

The most known factor responsible for virulence is the capsule, but there are also others, such as surface protein Rib, alpha antigens, etc. GBS strains are able to cause infections not only because of the development of resistance to antibiotics but also due to their virulence traits. ${ }^{15} \mathrm{~A}$ wide variety of surface proteins contribute to the pathogenesis of GBS infection, and most of these multifunctional proteins are involved in the adhesion and invasion of the bacteria to the host cell, as well as in the evasion of the host immune responses. ${ }^{16}$ The $\alpha-C$ protein encoded by the bca gene has important role in adherence of bacterial cells to the cervical epithelial cells ${ }^{17}$, invasion of epithelial cells, as well as resistance to phagocytosis. The $b c a$ gene was generally found in Ia, Ib and II GBS serotypes, and in $15 \%$ of isolates of serotype $\mathrm{V}$. The repeat numbers of the $\alpha-C$ protein are not different between invasive and carriage strains. ${ }^{15}$

The Rib protein encoded by the rib gene is very identical to the $\alpha$-C protein and a great number of the invasive strains express this protein. ${ }^{17}$ Rib protein has been found in significant percentage of GBS strains which caused invasive infections in neonates. It was observed that the presence of antibodies against those proteins protected neonates from invasive infection by strains expressing Rib protein. ${ }^{15}$ Also it was shown that immunization of mice with components of purified Rib protein protected them from fatal infection caused by a strain possessing similar type of Rib protein. ${ }^{15}$

Currently, vaccines targeting CPS from GBS serotypes Ia, Ib, II, III, V ${ }^{18}$ (the five widely known prevalent serotypes in other regions in the world which are considered as candidates for pentavalent CPS-conjugate vaccine), and those directed at $\alpha-C$ protein and Rib protein are under clinical trials. The reported frequency of GBS serotypes differ in different countries in the world, thus serotypes Ia, Ib, II, III, V were found to be the common ones causing GBS diseases in some countries, ${ }^{19}$ while in Malaysia it was serotypes Ia, III, IV, V, and VI. ${ }^{20}$ Thus, the vaccines which target CPS need to give broad protection against most GBS serotypes $^{19}$ in order to overcome the issue of discrepancy in serotype distribution.

The aim of this study is to find out the distribution of various GBS CPS serotypes and determine the frequency of virulence genes $b c a$ and $r i b$, in GBS isolates from vaginal swabs of symptomatic pregnant women. 


\section{MATERIALS AND METHODS}

A total of 62 GBS isolates were collected from $1^{\text {st }}$ of March 2018 to 30th of July 2018 from Microbiology lab, Pathology Department of Hospital Tengku Ampuan Afzan (HTAA), Kuantan, Pahang. The isolates were obtained from women 16 to 46 years old with symptoms of either preterm labour at $<37$ week gestation, preterm premature rupture of membrane (PPROM) for $\geq 18 \mathrm{~h}$, intrapartum fever, vaginal discharge, or lower abdominal pain with suspicion of pelvic inflammatory disease.

The GBS isolates were re-confirmed as GBS using conventional PCR targeting $c f b$ gene (Table I). The $c f b$ gene codes for GBS extracellular protein called CAMP factor which has been used for the presumptive identification of this streptococcus. ${ }^{21}$ DNA of the bacterial isolates was extracted using Presto ${ }^{\mathrm{TM}}$ Mini gDNA Bacteria Kit (Geneaid New Taipei). The PCR mixture each comprising of GoTaq Green Master Mix reagent (Promega, Madison, USA) $12.5 \mu \mathrm{L}$, forward and reverse primers $(10 \mu \mathrm{M}), \quad 2.5 \mu \mathrm{L}$ each (final concentration of $1.0 \mu \mathrm{M}$ ), template DNA $5 \mu \mathrm{L}$ (final concentration $<250 \mathrm{ng}$ ), and nuclease free water $2.5 \mu \mathrm{L}$ to a final volume of $25 \mu \mathrm{L}$ were used, running thermal cycler with gradient (Eppendorf, New York). The reaction was performed at initial activation at $95^{\circ} \mathrm{C}$ for 120 seconds, subsequent denaturation step at $95^{\circ} \mathrm{C}$ for 30 seconds, annealing of complementary primers for the hybridization step at $58.2^{\circ} \mathrm{C}$ for 30 seconds, extension period of $72^{\circ} \mathrm{C}$ for 60 seconds, and final extension at $72^{\circ} \mathrm{C}$ for 300 seconds, by 30 cycles.

Serotyping was performed using Group B Streptococcus typing sera kit (Denka Seiken, Tokyo) for GBS serotypes Ia, Ib, II - VIII. All GBS isolates were also serotyped using Immulex Latex Agglutination Streptococcus B antisera for serotype IX (Staten Serum Institute; Copenhagen). GBS was sub-cultured in $5 \mathrm{~mL}$ of Todd-Hewitt broth medium (OXOID, Basingstoke) and incubated at $30^{\circ} \mathrm{C}$ for $16-20$ hours. The test antigen was prepared using Auxiliary Reagent for Haemolytic Streptococcus Typing Kit (Denka Seiken, Tokyo). A strong agglutination reaction between the test antigen and antisera within one minute showed that the sample is positive for a particular serotype, as shown in Figure 1. For serotype IX, a drop of approximately $10 \mu \mathrm{L}$ of the latex reagent was added to $10 \mu \mathrm{L}$ of THB culture and was mixed, and the sample was interpreted as positive, if agglutination was visible after 30 seconds.

For detection of rib and $b c a$ genes, all isolates were analysed using primers targeting rib and bca genes Table I.

Table I: Specific primer for $r i b, b c a$ and $c f b$ genes

\begin{tabular}{|c|c|c|c|}
\hline Gene & Sequence & $\begin{array}{l}\text { Amplicons } \\
\text { bp }\end{array}$ & $\begin{array}{l}\text { Gene } \\
\text { bank } \\
\text { accession } \\
\text { no. }\end{array}$ \\
\hline \multirow[t]{2}{*}{$\mathrm{cfb}$} & $\begin{array}{l}\text { Forward } 5^{\prime}-3^{\prime} \\
\text { TCACCAGCTGTATTAG } \\
\text { AAGTA }\end{array}$ & & \\
\hline & $\begin{array}{l}\text { Reverse 5'-3' } \\
\text { GTTCCCTGAACATTAT } \\
\text { CTTTGAT } \\
\text { (IDT) }\end{array}$ & 153 bp & lcl-76021 \\
\hline \multirow[t]{2}{*}{ rib } & $\begin{array}{l}\text { Forward5'-3' } \\
\text { CAGGAAGTGCTGTTA } \\
\text { CGTTAAAC }\end{array}$ & & \\
\hline & $\begin{array}{l}\text { Reverse } 5^{\prime}-3^{\prime} \\
\text { CGTCCCATTTAGGGTC } \\
\text { TTCC } \\
\text { (IDT) }\end{array}$ & $369 \mathrm{bp}$ & U58333.1 \\
\hline \multirow[t]{2}{*}{ bca } & $\begin{array}{l}\text { Forward } 5^{\prime}-3^{\prime} \\
\text { CAG GAG GGG AAA } \\
\text { CAA CAG TAC }\end{array}$ & & \\
\hline & $\begin{array}{l}\text { Reverse } 5^{\prime}-3^{\prime} \\
\text { GTA TCC TTT GAT } \\
\text { CCA TCT GGA TAC G } \\
\text { (IDT) }\end{array}$ & $183 \mathrm{bp}$ & M97256.1 \\
\hline
\end{tabular}

(Esleem et al.,2017;17 Laczeski et al.,2015;22 Sadaka et al.,201823)

The final volume of $25 \mu \mathrm{L}$ of PCR reaction mixture contained GoTaq ${ }^{\circledR}$ qPCR mastermix (Promega, USA), nuclease free water, template DNA and specific primer pairs. Non template control samples containing water substituted in place of cDNA were included in all assays to confirm the absence of non-specific amplification product.

The reaction was performed at hot-start activation temperature of $95^{\circ} \mathrm{C}$ for 2 minutes, denaturation at $95^{\circ} \mathrm{C}$ for 15 seconds, annealing/extension $57^{\circ} \mathrm{C}$ for rib gene and $60^{\circ} \mathrm{C}$ for $b c a$ gene, by 40 cycles and melt curve from $65^{\circ} \mathrm{C}$ to $95^{\circ} \mathrm{C}$ for 5 seconds per step. The DNA from a reference strain was used as positive control to check for presence of any PCR inhibitors. The raw data were analysed using Bio-Rad CFX Manager software (version 3.0) with melting curve analysis. Few samples 
were selected randomly to be assessed by sequencing of PCR products derived from GBS strains to confirm specificity of primers. The sequencing data were verified by importing them using Sequence Scanner Software 2, followed by BLAST. Base sequence analysis of the GBS isolates $c f b$, rib, and $b c a$ genes was performed individually against the GenBank database sequences to obtain the most closely related sequence matches.

The Statistical Package for Social Science (SPSS) (version 20 for Windows software) was used to analyse the results. The categorical data were expressed in frequency. The differences between two categorical variables were examined, using chi-square and Fisher Exact test. A probability level of less than 0.05 is considered as statistically significant.

\section{RESULTS}

The conventional PCR assay targeting $c f b$ gene was positive for all 62 GBS isolates from symptomatic pregnant women. The quality of amplified DNA was evaluated using gel electrophoresis, where all samples revealed single bands of the expected size (153bp), as shown in Figure 1.

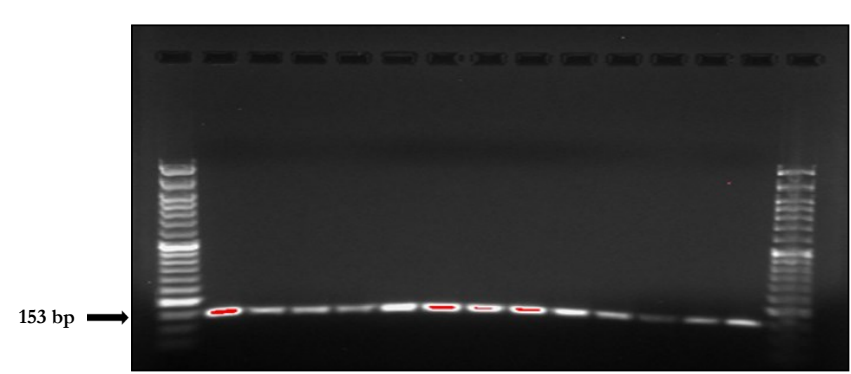

Figure 1: Agarose gel electrophoresis of PCR product of GBS $c f b$ gene. Lane 1 and $15=$ DNA ladder $(50 \mathrm{bp})$, lane $2=$ positive control, other lanes=positively amplified gene with correctly expected band size of $153 \mathrm{bp}$

Collectively, $77.4 \%$ (48 out of 62 ) of GBS isolates were serologically typeable, however $22.6 \%$ (14 out of 62 ) were non-typeable. Serotypes Ia and Ib were the most frequent capsular types (16.1\% each), followed by II, V and VII (9.7\% each), III (8.10\%), VI (6.5\%), and VIII $(1.6 \%)$ the least frequent. The overall serotype distribution of GBS is shown in Figure 2. Serotypes IV and IX were not found among the samples.

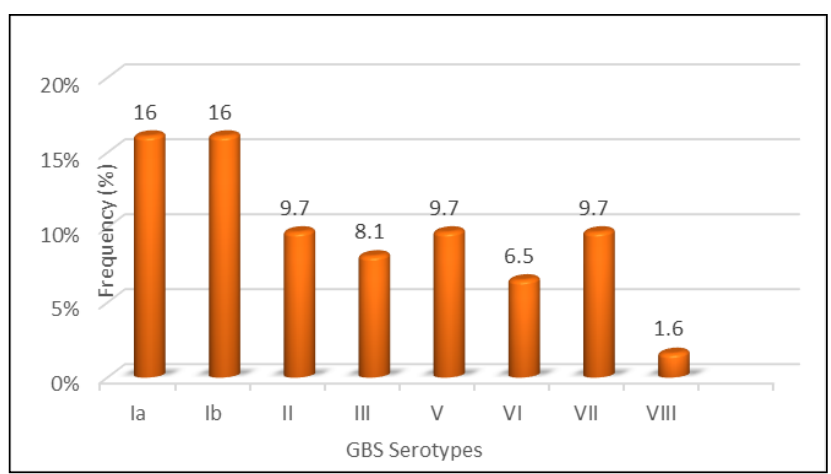

Figure 2: Frequency distribution of GBS serotypes among isolates from symptomatic pregnant women $(n=62)$

Of 62 GBS isolates, $42(67.7 \%)$ were found to harbour rib gene as revealed by real-time PCR. The presence of the rib and bca gene was confirmed by melt curve analysis revealing a single peak with melting temperature of 74 and $80^{\circ} \mathrm{C}$ which is comparable to the melting temperature of the positive control.

To confirm specific amplification of the target segment, the real-time PCR products were visualized on $2 \%$ agarose gel electrophoresis and all positive samples revealed target gel bands with the size of 369 bp for rib and 183 bp for bca gene.

The highest frequency of detection of rib gene was found among serotype Ib isolates and the lowest among serotypes VI and VIII. The distribution of rib and $b c a$ among all serotypeable and non-serotypeable GBS isolates is summarized in Table II.

Table II: Frequency of rib and bca genes across the 62 GBS serotypes

\begin{tabular}{ccc}
\hline GBS Serotypes & rib & bca \\
{$[\mathrm{N}(\%)]$} & {$[\mathrm{N}(\%)]$} \\
\hline Ia & $6(9.7)$ & $9(14.5)$ \\
Ib & $7(11.3)$ & $10(16.1)$ \\
II & $3(4.8)$ & $6(9.7)$ \\
III & $4(6.5)$ & $5(8.1)$ \\
IV & $0(0.0)$ & $0(0.0)$ \\
V & $6(9.7)$ & $6(9.7)$ \\
VI & $1(1.6)$ & $4(6.5)$ \\
VII & $3(4.8)$ & $6(9.7)$ \\
VIII & $1(1.6)$ & $1(1.6)$ \\
IX & $0(0.0)$ & $0(0.0)$ \\
NT* & $11(17.1)$ & $14(22.5)$ \\
Total & $62(100)$ & $62(100)$ \\
\hline
\end{tabular}

*NT: Non-typeable

All GBS isolates of serotypes Ib, II, III, V, VII, and VIII were found to be positive for bca gene. The only GBS isolate negative for $b c a$ gene was with Ia serotype (1 out of 10$)$. 
The Fisher`s exact test was applied in order to find association between the distribution of rib and $b c a$ genes as shown in Table III. Based on BLAST analysis, all the sequenced amplicons displayed 99\% to 100\% identity with all three corresponding genes $c f b$, rib, and $b c a$ from reference GBS strains.

Table III: Association between rib and bca genes among GBS isolates

\begin{tabular}{cccc}
\hline \multirow{2}{*}{$\begin{array}{c}\text { GBS virulence factors } \\
\text { genes }\end{array}$} & \multicolumn{2}{c}{$\begin{array}{c}\text { Distribution among GBS } \\
\text { isolates [n(\%)] }\end{array}$} & P-Value \\
\cline { 2 - 3 } & Present & Absent & \\
$r i b$ & $42(67.7)$ & $20(32.3)$ & 0.323 \\
$b c a$ & $61(98.4)$ & $1(1.6)$ & \\
\hline
\end{tabular}

Fisher`s exact test applied. Level of significance was set at 0.05. There is not enough evidence to suggest an association between rib and $b c a$ virulence genes among the GBS isolates $(p=0.323)$

\section{DISCUSSION}

Group B Streptococcus (GBS) is one of the pathogens which infects pregnant women and through them affects their neonates. ${ }^{24}$ The major risk factor that contributes to the development of invasive GBS disease in offspring is maternal recto-vaginal colonization and ascending intrauterine infection during pregnancy. ${ }^{4}$ Deficiencies in IAP strategies and their inability to prevent LOD, made it clear that administration of a suitable vaccine in pregnancy could provide a better solution, and besides that it would be cost effective. ${ }^{19}$

Data on GBS serotypes and virulence genes distribution are not existent in Kuantan. Although there are data on serotype and virulence genes distribution in Kuala Lumpur, but the data is not focused on symptomatic pregnant women.9,20 Therefore, it is evident that there is lack of data on the GBS distribution of serotypes and virulence factors among symptomatic pregnant women, in Malaysia. Thus, this current study was proposed and conducted to partially fill in this gap in knowledge.

Serotype Ia was found to be the most common serotype in isolates derived from symptomatic patients, pregnant and non-pregnant females and males, who were mostly diabetic and/or immunocompromised patients due to medication. ${ }^{25,26}$ Similarly, we also found that serotype $\mathrm{Ia}$ is the most common serotype in symptomatic pregnant women.

Among 310 cases of maternal GBS disease (in pregnant women or within 42 days postpartum) globally, serotype Ia was shown as the most common one (31\%), followed by Ib (14\%), II (5\%), III (27\%), and V $(19 \%) .{ }^{27}$ The high frequency of serotypes Ia, Ib, II and $\mathrm{V}$ is in accord with the most frequent serotypes in our study. Conversely, serotype VII was predominant in our study, but serotype III is the one predominant globally which reflects geographical difference.

According to a GBS study in the University of Malaya Medical Centre (UMMC) among the vaginal isolates from 200 asymptomatic pregnant Malaysian women, the most common five serotypes were Ia $(11.5 \%)$, III $(12 \%), \operatorname{IV}(10 \%), \mathrm{V}(19 \%)$, and VI $(17 \%) .{ }^{20}$ In the present study on symptomatic Malaysian pregnant women the common serotypes are $\mathrm{Ia}$ and $\mathrm{Ib}, \mathrm{II}, \mathrm{V}$, and VII. Overall, serotype distribution seems to be varied between symptomatic and asymptomatic pregnant women. Therefore, to plan for a vaccine with broader coverage, collecting data on bacterial serotypes of pregnant women of both categories may be required.

The GBS data obtained from this study and other local studies are not quite sufficient yet to plan for the best preventative control strategy for GBS infections in mothers in Malaysia. It is due to limited samples used in the studies. Moreover, the data obtained from nonpregnant women, neonates, and men is pooled together in some studies, but these studies can be used as basement for better planning new studies.

In Norway, Maeland et al. found that $100 \%$ of GBS strains type Ia (but there only one serotype was tested) have bca gene. ${ }^{28}$ While Lysakowska et al. (2011) ${ }^{15}$ found a higher frequency $(80 \%)$ of the virulence factor gene $b c a$ in all forty of GBS strains of different serotypes isolated from pregnant women in Poland. Hannoun et al. (2010) ${ }^{29}$ also found high frequency $(56.5 \%)$ of $b c a$ in 76 pregnant women near term in Lebanon. Manning et al. $(2006)^{30}$ found $b c a$ gene at higher frequency $46 \%$ in 'colonizing strains' from pregnant women vs $29 \%$ among 'invasive strains' isolated from neonate with 
GBS disease. These studies show the high frequency of bca gene among colonizing strains which is in concordance with the current study.

Similarly, high frequencies of virulence genes rib and $b c a$ in pregnant women $(\mathrm{n}=88)$ were reported by Oviedo et al. in Argentina to be $88.6 \%$ and $76.1 \%$, respectively. ${ }^{31}$ The frequency of rib was higher than in the present study, while that of $b c a$ is higher in present study. The main point is similar high frequency of both genes in colonizing strains. Comparison of rib and $b c a$ genes distribution in different geographical locations is tabulated in Tables IV and V, respectively.

Lopez et al. (2017) ${ }^{32}$ found that GBS virulence genes showed higher prevalence of $b c a$ and rib in symptomatic pregnant women compared to asymptomatic pregnant women in Spain. Among 95 asymptomatic pregnant women colonized by GBS, the frequencies of rib and $b c a$ genes was $64.2 \%$ and $21.1 \%$, respectively. On the other hand, among 68 infected symptomatic pregnant women the rib and $b c a$ genes were detected in $72.1 \%$ and $45.6 \%$ of GBS isolates respectively. Thus, these findings are concordant with ours showing a higher occurrence of rib and bca virulence genes among symptomatic pregnant women. The more frequent presence of rib and $b c a$ genes among symptomatic pregnant women may reflect their importance in pathogenesis of GBS infections in pregnant women and their offspring, thus conferring higher virulence to GBS strains harbouring them. This role in pathogenicity can be clearly seen in Lopez study and present study (Tables IV), where the frequency of virulence genes was high among symptomatic pregnant women. As a result, the frequency of these genes is higher in symptomatic pregnant women and then in colonizing asymptomatic pregnant women than invasive GBS patients.

Analogous to our study, Łysakowska et al. (2011)15 statistical analysis revealed no association between the presence of rib and presence of $b c a$ genes, however this finding may also be due to their low sample size. In the present study, Chi-square test showed that the expected frequencies for $b c a$ and rib genes were $66.7 \%$ and $83.3 \%$, respectively, which made this test unreliable for finding significant association between rib, bca genes and GBS serotypes to find which serotype expresses either rib or $b c a$ gene. Thus, due to the small sample size we used the Fisher Exact test in place of Chi-square test in a 2 by 2 table.

The pentavalent CPS conjugate vaccine comprising serotypes Ia, Ib, II, III, and V will not cover for all GBS serotypes among symptomatic pregnant women in this area. Our findings also showed the wide distribution of the virulence genes rib and $b c a$ among GBS strains from symptomatic pregnant women. The serotype based and protein-based vaccines are under trial and we found the distribution of two virulence factor genes which is included in one of these protein-based vaccines. Conservatively in view of our limited data, we tentatively believe that the proteinaceous vaccine $\mathrm{N}$ terminal domains of Rib and $\alpha$-C, may be a better preventative option to cover for variations in GBS serotypes in this region. However, the isolates we assessed may possess other virulence genes, as the virulence of GBS is probably attributable to multiple genes and their products. It is also possible that these virulence genes may be differentially expressed. That is why there is a need to conduct further research on the prevalence and expression of other virulence genes among pregnant women to deduce the best candidate.

\section{CONCLUSION}

This is the first study in Kuantan, which reports the GBS serotypes and virulence genes distribution among symptomatic pregnant women. This study also highlighted some differences in serotype distribution in symptomatic compared to asymptomatic pregnant women as reported in previous studies. ${ }^{20}$

In planning for a preventative strategy to GBS infection in pregnant women, the distribution of serotypes and virulence genes should be investigated in both symptomatic and asymptomatic pregnant women. In present study, serotypes V, VI, III, Ia, and IV were identified as the five most common serotypes in symptomatic pregnant women, while in asymptomatic pregnant women according Dhanoa et al. (2010) ${ }^{20}$ they were serotypes Ia, Ib, V, II, and VII. The pentavalent CPS conjugate vaccine (for serotypes Ia, Ib, II, III, and V) will not cover for all GBS infections among 
Table IV: Comparison of rib and bca gene distribution in different geographical locations

\begin{tabular}{|c|c|c|c|c|c|c|}
\hline Author, Year & $\begin{array}{l}\text { Study } \\
\text { place }\end{array}$ & $\begin{array}{l}\text { Study } \\
\text { population }\end{array}$ & $\begin{array}{l}\text { Sample } \\
\text { size (n) }\end{array}$ & $\begin{array}{l}\text { rib gene } \\
\text { frequency }(\%)\end{array}$ & $\begin{array}{l}\text { bca gene } \\
\text { frequency } \\
(\%) \\
\end{array}$ & $\begin{array}{l}\text { Serotype } \\
\text { distribution }\end{array}$ \\
\hline $\begin{array}{l}\text { Hannoun et al., } \\
2010\end{array}$ & Lebanon & $\begin{array}{l}\text { pregnant } \\
\text { women near } \\
\text { term }\end{array}$ & 76 & 33 & 56.5 & Not investigated* \\
\hline $\begin{array}{l}\text { Łysakowska et } \\
\text { al., } \\
2011\end{array}$ & Poland & $\begin{array}{l}\text { pregnant } \\
\text { women }\end{array}$ & 40 & 35 & 80 & Not investigated* \\
\hline $\begin{array}{l}\text { Oviedo et al., } \\
2012\end{array}$ & Argentina & $\begin{array}{l}\text { pregnant } \\
\text { women }\end{array}$ & 88 & 76.1 & 88.6 & $\begin{array}{l}\text { Ia }(40 \%), \text { III }(21 \%), \\
\text { V }(12 \%), \text { II }(10 \%), \text { Ib } \\
(9 \%), \text { IX }(4 \%) / 112 \\
\text { GBS strains }\end{array}$ \\
\hline $\begin{array}{l}\text { Lopez et al., } \\
2017\end{array}$ & Spain & $\begin{array}{l}\text { Symptomatic } \\
\text { pregnant } \\
\text { women }\end{array}$ & 68 & 72.1 & 21.1 & $\begin{array}{l}\text { III, II and IV }(38.2 \% \text {, } \\
22.1 \% \text { and } 13.2 \% \text {, } \\
\text { respectively) }\end{array}$ \\
\hline $\begin{array}{l}\text { Lopez } \\
2017\end{array}$ & Spain & $\begin{array}{l}\text { Asymptomatic } \\
\text { pregnant } \\
\text { women }\end{array}$ & 95 & 64.2 & 45.6 & $\begin{array}{r}\text { II }(31.6 \%), \\
\text { III }(26.3 \%) \\
\text { Ia }(17.9 \%)\end{array}$ \\
\hline $\begin{array}{l}\text { current study } \\
2018\end{array}$ & $\begin{array}{l}\text { Malaysia } \\
\text { Kuantan }\end{array}$ & $\begin{array}{l}\text { Symptomatic } \\
\text { pregnant } \\
\text { women }\end{array}$ & 62 & 67.7 & 98.4 & $\begin{array}{l}\text { Ia, Ib }(16.1 \%), \text { II, V, } \\
\text { VII }(9.7 \%), \text { III } \\
(8.1 \%), \text { VI }(6.5 \%) \text {, } \\
\text { VIII }(1.6 \%)\end{array}$ \\
\hline
\end{tabular}

* Not investigated by the authors

symptomatic pregnant women in this area, but may probably protect for a high percentage of them.

Our findings, show the high prevalence of the virulence genes rib (67.7\%) and bca (98.4\%) among the isolates from symptomatic pregnant women. In view of our data, proteinaceous vaccine, N-terminal domains of Rib and $\alpha-C$ which is under clinical trial, could probably be a better preventative option in order to cover more GBS cases in this region, but this requires further studies.

There is a real need to conduct further research on a larger and wider scale that includes various states in Malaysia in order to more precisely determine the prevalence of the various capsular serotypes, their virulence genes and their expressed phenotypes among asymptomatic and symptomatic pregnant women. The knowledge that would be obtained from such studies would be decisive for choosing either an already available GBS vaccine or the development of a new one for this geographical area.

\section{REFERENCES}

1. Whidbey CM. Characterization of the group $B$ Streptococcus hemolysin and its role in intrauterine infection (Doctoral dissertation), University of Washington, 2015.

2. Lin SM, Zhi Y, Ahn KB, Lim S, Seo HS. Status of group B streptococcal vaccine development. Clinical and Experimental Vaccine Research. 2018 Jan 1;7(1):76-81.

3. Stoll BJ, Holman RC, Schuchat A. Decline in sepsis-associated neonatal and infant deaths in the United States, 1979 through 1994. Pediatrics. 1998 Aug 1;102(2):e18.

4. Edmond KM, Kortsalioudaki C, Scott S, Schrag SJ, Zaidi AK, Cousens S, Heath PT. Group B streptococcal disease in infants aged younger than 3 months: systematic review and metaanalysis. The Lancet. 2012 Feb 11;379(9815):547 -56 .

5. Dzanibe $S$. Natural induced antibodies against group $B$ streptococcus surface proteins and capsular polysaccharides (Doctoral dissertation), University of Witwatersrand 2017.

6. Russell NJ, Seale AC, O’Driscoll M, O’Sullivan C, Bianchi-Jassir F, Gonzalez-Guarin J, Lawn JE, Baker CJ, Bartlett L, Cutland C, Gravett MG. Maternal colonization with group B

Streptococcus and serotype distribution worldwide: systematic review and meta-analyses. Clinical Infectious Diseases. 2017 Nov 6;65 (suppl_2):S100-11.

7. Huang J, Li S, Li L, Wang X, Yao Z, Ye X. Alarming regional differences in prevalence and antimicrobial susceptibility of group B streptococci in pregnant women: A systematic 
review and meta-analysis. Journal of Global Antimicrobial Resistance. 2016 Dec 1;7:169-77.

8. Eskandarian N, Neela V, Ismail Z, Puzi SM, Hamat RA, Desa MN, Nordin SA. Group B streptococcal bacteremia in a major teaching hospital in Malaysia: a case series of eighteen patients. International Journal of Infectious Diseases. 2013 Sep 1;17(9):e777-80.

9. Eskandarian N, Ismail Z, Neela V, Van Belkum A, Desa MN, Nordin SA. Antimicrobial susceptibility profiles, serotype distribution and virulence determinants among invasive, noninvasive and colonizing Streptococcus agalactiae (group B streptococcus) from Malaysian patients. European Journal of Clinical Microbiology \& Infectious Diseases. 2015 Mar 1;34(3):579-84.

10. Verani JR, McGee L, Schrag SJ. Prevention of perinatal group B streptococcal disease. Morbidity and Mortality Weekly Report (MMWR), Revised Guidelines from CDC, Recommendations and Reports. 2010 Jun 18;59 (RR10):1-32.

11. Madhi SA, Koen A, Cutland CL, Jose L, Govender N, Wittke F, Olugbosi M, Sobanjo-ter Meulen A, Baker S, Dull PM, Narasimhan V. Antibody kinetics and response to routine vaccinations in infants born to women who received an investigational trivalent group $B$ Streptococcus polysaccharide CRM197-conjugate vaccine during pregnancy. Clinical Infectious Diseases. 2017 Nov 13;65(11):1897-904.

12. Arakere G, Flores AE, Ferrieri P, Frasch CE. Inhibition enzyme-linked immunosorbent assay for serotyping of group B streptococcal isolates. Journal of Clinical Microbiology. 1999 Aug 1;37 (8):2564-7.

13. Lancefield RC. A serological differentiation of specific types of bovine hemolytic streptococci (group B). The Journal of Experimental Medicine. 1934 Mar 31;59(4):441.

14. Imperi M, Pataracchia M, Alfarone G, Baldassarri L, Orefici G, Creti R. A multiplex PCR assay for the direct identification of the capsular type (Ia to IX) of Streptococcus agalactiae. Journal of Microbiological Methods. 2010 Feb 1;80(2):2124.
15. Lysakowska ME, Kalinka JA, Bigos MO, Prosniewska MA, Wasiela MA. Occurrence of virulence genes among $\mathrm{S}$. agalactiae isolates from vagina and anus of pregnant women-a pilot study. Arch Perinat Med. 2011;17(4):229-34.

16. Ke D, Ménard C, Picard FJ, Boissinot M, Ouellette M, Roy PH, Bergeron MG.

Development of conventional and real-time PCR assays for the rapid detection of group $B$ streptococci. Clinical chemistry. 2000 Mar 1;46 (3):324-31.

17. Esleem SE. Prevalence of Streptococcus agalactiae Colonization among Pregnant Women in Gaza city, Palestine. Prevalence of Streptococcus agalactiae Colonization among Pregnant Women in Gaza city, Palestine. (Master Thesis) The Islamic University- Gaza 2017.

18. Li S, Wen G, Cao X, Guo D, Yao Z, Ye X. Molecular characteristics of Streptococcus agalactiae in a mother-baby prospective cohort study: implication for vaccine development and insights into vertical transmission. Vaccine. 2018 Apr 5;36(15):1941-8.

19. Kobayashi M, Schrag SJ, Alderson MR, Madhi SA, Baker CJ, Sobanjo-ter Meulen A, Kaslow DC, Smith PG, Moorthy VS, Vekemans J. WHO consultation on group B Streptococcus vaccine development: report from a meeting held on 2728 April 2016. Vaccine. 2019 Nov 28;37 (50):7307-14.

20. Dhanoa A, Karunakaran R, Puthucheary SD. Serotype distribution and antibiotic susceptibility of group B streptococci in pregnant women. Epidemiology \& Infection. 2010 Jul;138(7):97981.

21. Rajagopal L. Understanding the regulation of Group B Streptococcal virulence factors.

22. Laczeski M, Novosak M, Giolito RC, Littvik A, Paván J, Villalba V, Vergara M. Study of Serotypes, Susceptibility to Macrolide and Virulence and Resistance Molecular Profiles in Invasive Strains of Streptococcus agalactiae in Two Argentine Provinces. Advances in Microbiology. 2015 Apr 1;5(04):230.

23. Sadaka SM, Aly HA, Meheissen MA, Orief YI, Arafa BM. Group B streptococcal carriage, antimicrobial susceptibility, and virulence related 
genes among pregnant women in Alexandria, Egypt. Alexandria Journal of Medicine. 2018 Apr 19;54(1):69-76.

24. Stoll BJ, Hansen NI, Sánchez PJ, Faix RG, Poindexter BB, Van Meurs KP, Bizzarro MJ, Goldberg RN, Frantz ID, Hale EC, Shankaran S. Early onset neonatal sepsis: the burden of group B Streptococcal and E. coli disease continues. Pediatrics. 2011 May 1;127(5):817-12.

25. Karunakaran R, Raja NS, Hafeez A, Puthucheary SD. Group B Streptococcus infection: epidemiology, serotypes, and antimicrobial susceptibility of selected isolates in the population beyond infancy (excluding females with genital tract-and pregnancy-related isolates) at the University Malaya Medical Centre, Kuala Lumpur. Jpn J Infect Dis. 2009 May 1;62(3):1924.

26. Suhaimi ME, Desa MN, Eskandarian N, Pillay SG, Ismail Z, Neela VK, Masri SN, Nordin SA. Characterization of a Group B Streptococcus infection based on the demographics, serotypes, antimicrobial susceptibility and genotypes of selected isolates from sterile and non-sterile isolation sites in three major hospitals in Malaysia. Journal of infection and public health. 2017 Jan 1;10(1):14-21.

27. Hall J, Adams NH, Bartlett L, Seale AC, Lamagni T, Bianchi-Jassir F, Lawn JE, Baker CJ, Cutland C, Heath PT, Ip M. Maternal disease with group B Streptococcus and serotype distribution worldwide: systematic review and meta-analyses. Clinical infectious diseases. 2017 Nov 6;65 (suppl_2):S112-24.

28. Maeland JA, Brakstad OG, Bevanger L, Krokstad S. Distribution and expression of bca, the gene encoding the $\mathrm{c}$ alpha protein, by Streptococcus agalactiae. Journal of Medical Microbiology. 2000 Feb 1;49(2):193-8.

29. Hannoun A, Shehab M, Khairallah MT, Sabra A, Abi-Rached R, Bazi T, Yunis KA, Araj GF, Matar GM. Correlation between group B streptococcal genotypes, their antimicrobial resistance profiles, and virulence genes among pregnant women in Lebanon. International Journal of Microbiology. 2009 Jan 1;2009.
30. Manning SD, Springman AC, Lehotzky E, Lewis MA, Whittam TS, Davies HD. Multilocus sequence types associated with neonatal group $\mathrm{B}$ streptococcal sepsis and meningitis in Canada. Journal of Clinical Microbiology. 2009 Apr 1;47 (4):1143-8.

31. Oviedo P, Pegels E, Laczeski M, Quiroga M, Vergara M. Phenotypic and genotypic characterization of Streptococcus agalactiae in pregnant women: first study in a province of Argentina. Brazilian Journal of Microbiology. 2013;44(1):253-8.

32. López Y, Parra E, Cepas V, Sanfeliú I, Juncosa T, Andreu A, Xercavins M, Pérez J, Sanz S, Vergara A, Bosch J, Soto SM. Serotype, virulence profile, antimicrobial resistance and macrolideresistance determinants in Streptococcus agalactiae isolates in pregnant women and neonates in Catalonia, Spain. Enferm Infecc Microbiol Clin (Engl Ed). 2018 Oct;36(8):472477. 